ALEN JUGOVIĆ, Ph.D. ${ }^{1}$

E-mail: ajugovic@pfri.hr

MARIJAN CUKROV, Ph.D. ${ }^{2}$

(Corresponding author)

E-mail: cukrov@shortsea.hr

TANJA POLETAN JUGOVIĆ, Ph.D. ${ }^{1}$

E-mail: poletan@pfri.hr

${ }^{1}$ Faculty of Maritime Studies Rijeka, University of Rijeka

Studentska 2, 51000 Rijeka

2 Intermodal Transport Cluster

Trpimirova 2, 51000 Rijeka
Intermodal Transport

Preliminary Communication

Submitted: 15 Jan. 2017

Accepted: 3 July 2017

\title{
MULTI-CRITERIA OPTIMIZATION OF MOTORWAYS OF THE SEA IN THE FUNCTION OF THE ENVIRONMENT PROTECTION: CASE STUDY OF CROATIA
}

\begin{abstract}
The transport system causes extremely harmful consequences for society and the environment. It is manifested through the increased emission of harmful exhaust gases, traffic congestions, traffic accidents, increased level of noise, higher levels of stress and various diseases of all participants of the transport system and society in general. The implementation and modernization of intermodality through the Motorways of the Sea (MoS) as its ecological and socio-economic sustainable subsystem is the efficient way of reducing the above mentioned consequences. Further sustainable development of MoS can be observed according to the ecological and socio-economic criteria and sub-criteria set out in this paper in order to keep it in direct function of protecting the society and preserving the environment.
\end{abstract}

\section{KEY WORDS}

motorways of the sea; ports; environmental protection; intermodality; emissions of exhaust gases; external costs; sustainable development; energy efficiency;

\section{INTRODUCTION}

Motorways of the Sea (MoS) are maritime part of intermodal transport system that is integrated in a certain transport corridor in the so called door to door transport system. The idea is to establish efficient, effective, safe, regular and, according to the results of research, ecologically and socio-economically sustainable maritime line connections between the designated sea ports in a certain area. MoS, according to the research on the example of the Republic of Croatia, has the lowest total emissions of harmful exhaust gases, the lowest energy consumption, the highest energy efficiency and the lowest external transport costs per transported freight unit. In this paper, one TEU (twenty-foot equivalent unit - is an inexact unit of cargo capacity often used to describe the capacity of container ships and container terminals) of average mass of $20 \mathrm{t}$ has been taken as the freight unit (weighting factor), relevant for the calculation of the emissions of exhaust gases, energy efficiency and external transport costs. The proposed functioning models of port systems have been set with the tendency that maritime part of the corridors will be the longest part of the route. This means that its part in the total transport chain from door to door is the longest, regarding all the other transport systems. There is the tendency to use the railway transport system on the rest of the route (land part) in order to reduce the road system to a minimum. This is extremely important in order to reduce the entire negative impact of transport system on the environment, to contribute to energy efficiency and to reduce exhaust gases and external costs of transport costs. The mentioned can ensure efficient protection of society and environment.

The issue of implementing MoS based on ecological and socio-economic criteria is relatively new in scientific research; consequently, there is no large base of scientific and professional literature. Most of the data refer to the European Commission and its tendency for implementation of MoS in the European transport system. The above mentioned is attempted by enforcing projects financed by EU development funds and programs. In 2011, the European Commission adopted a new package of measures with the purpose of developing competitiveness and efficiency of the European transport system: White Paper: Roadmap to a Single European Transport Area - Towards a competitive and resource efficient transport system [1]. Special emphasis has been placed on the sustainable development and environmental protection. The main goal of the document is to reduce environmental pollution caused by traffic in general up to $60 \%$ until 2050. Also, it must be emphasised that EU funds will become available for sustainable transport systems while the MoS will become part of the Trans European 
traffic system. There are four key geographic areas for setting up the projects of European interest: Motorways of the Baltic Sea, MoS of Western Europe, MoS of South-East Europe, MoS of South-West Europe [2].

\section{RELEVANT CRITERIA REGARDING THE SUSTAINABILITY OF MOS}

The decision related to the selection of the transport route is based on several elements that make certain route more competitive than others [3]. This paper, based on the conducted research, shows and analyses those elements/criteria of corridors contributing to ecological protection. Contribution is provided through the reduction of total emission of harmful exhaust gases, reduction of energy consumption, increasing energy efficiency, reduction of total external costs of transport and optimization of existing infrastructure capacities of a particular transport service. Based on the aforementioned, there are criteria identified regarding transport route competitiveness in the function of environmental protection and their comparison in different scenarios has been displayed. Calculations related to specific criteria (corresponding sub-criteria) and their values required for the implementation of multi-criteria optimization were carried out for maritime, rail and road transport system. According to the identified gravitating seaport markets and defined transport corridors the calculated routes are the following: (1) Strait of Otranto-Zagreb (Croatia), (2) Strait of Otranto-Budapest (Hungary), (3) Strait of Otranto- Belgrade (Serbia), (4) Strait of Otranto-Sarajevo (Bosnia and Herzegovina), while using the following sea ports: Rijeka, Zadar, Šibenik, Split, Ploče and Dubrovnik.

\subsection{Criteria regarding emissions of harmful exhaust gases}

Traffic strongly affects the environment and society. Its influence is reflected in air pollution by emissions of harmful exhaust gases. The exhaust gases are related to air pollution. Some of them acting locally and directly on human health and on the destruction of flora and fauna, while others operate globally by causing global changes, so-called greenhouse effect, and negative influence on the economy [4]. In this paper, the following sub-criteria are set as Criteria of Emissions of Harmful Exhaust Gases: NOx - nitrogen oxides, SOx - Sulphur oxides, $\mathrm{CO}$ - carbon monoxide, $\mathrm{CO}_{2}$ - carbon dioxide, NMHC - non-methane hydrocarbons, PM 10 - particles (soot), Energy (power) consumption/energy efficiency.

Identifying and defining the criteria for evaluating the development and ecological sustainability of MoS is set on the basis of a detailed calculation and analysis of the above mentioned criteria and the related sub-criteria. Emissions of harmful exhaust gases in relation to the cargo unit (in this case one TEU, an average mass of $20 \mathrm{t}$ ) are calculated by the use of EcoTransIT computer program (http://www.ecotransit.org) [5]. The above mentioned program is the official computer program of the European Commission dealing with the calculation of the observed parameters and has been used for scientific research in this paper.

\subsection{Criteria regarding external costs of transport}

The concept of external costs in terms of the transport system defines the costs produced by the user of transport service, who does not pay for them even though they can be very high and harmful to the environment and society. Internal costs are the costs borne by the beneficiary, meaning, the one who had produced them by the organization of transport services [6]. For example, road tractor/truck located in the congestion produces costs to itself (lost time, extra fuel consumption, etc.) and to others (costs that the user does not cover and which are extremely harmful to the environment and society). In this paper the following categories of external costs are set as sub-criteria of the implementation of MoS in the function of environmental protection: air pollution costs, climate changes costs, costs caused by noise of transport systems, traffic accidents costs and traffic congestion costs. Based on the mentioned the authors have set the following formula [7]:

$$
E T=\frac{s}{1,000} \cdot t \cdot k
$$

where:

$\mathrm{s}$-distance $[\mathrm{km}]$,

$t$ - mass [t],

$k$ - coefficient [euro/1,000 tkm],

$E T$-external cost of transport service.

External cost coefficients used for the calculation are based on methodologies and/or values recommended by the estimation of external costs in the transport sector related to the Marco Polo freight transport project proposals defined by the European Commission. The recommended values and methodologies represent the state of the art and best practice on external cost estimation. The coefficients indicate the monetary costs of transport services in the Euro currency according to the 1,000 ton-kilometres [8].

\section{PORT MODEL SYSTEM DESIGN}

The proposed models of functioning of the port systems (on the example of the Republic of Croatia) have been set with already mentioned parameters and in relation to the existing situation of infrastructure capacities of certain sea ports. The above mentioned applies to six sea ports open to international trade as defined in Figure 1. The selection of sea port or establishing 


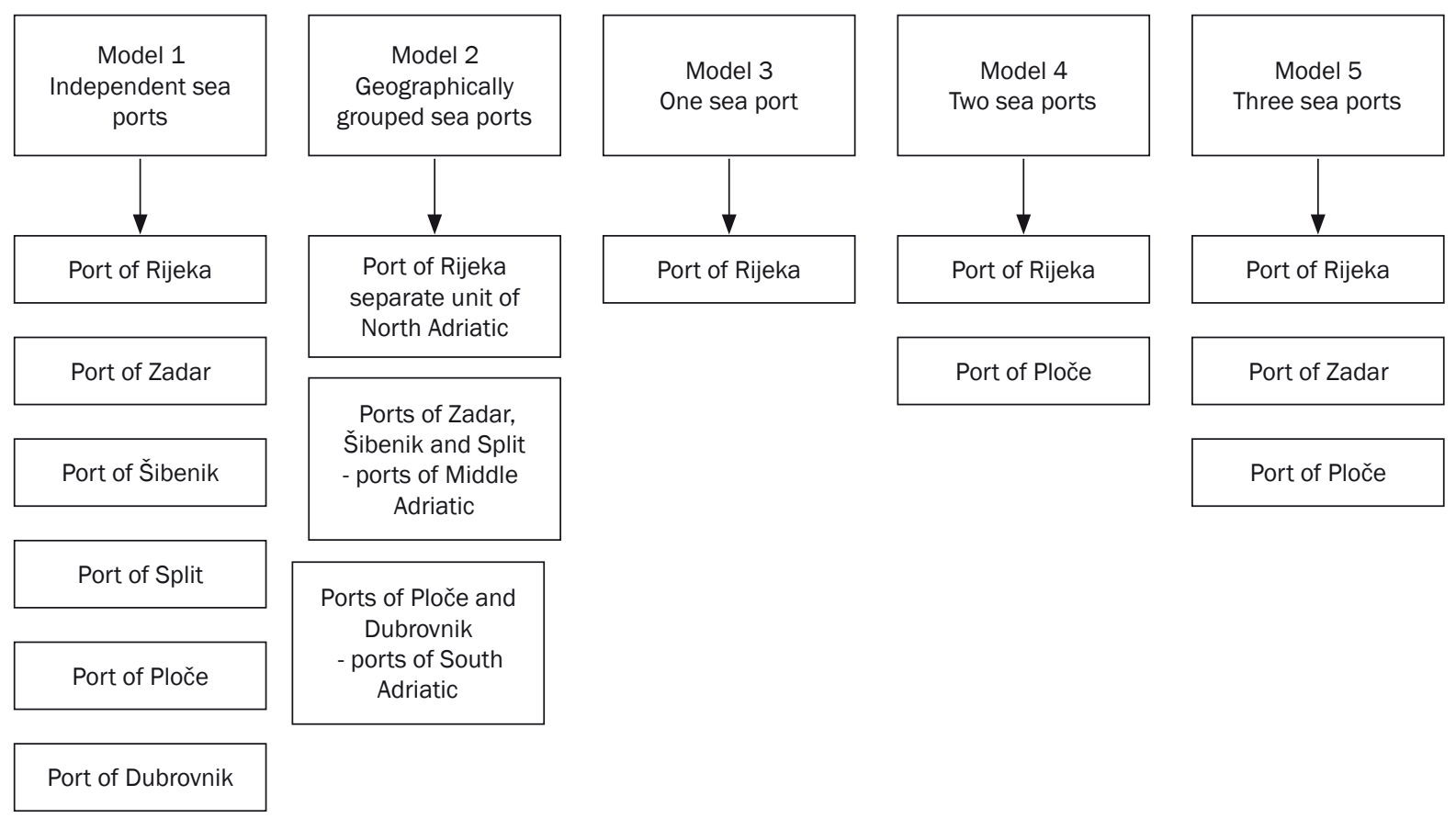

Figure 1 - Overview of defined port model systems [7]

certain models of functioning of the entire port system can greatly affect the reduction of environmental pollution. Models can contribute to the reduction of emissions of harmful exhaust gases and external costs of transport, and it can increase energy efficiency on the entire transport route. Ecological and socio-economical sustainable transport route may attract more cargo and thus achieve greater social and economic impact on the area of implementation of MoS, especially in densely populated urban areas.

The model of development, specialization and association of certain sea ports in a certain area in order to protect the environment due to the implementation of MoS is difficult to anticipate and define without systematic analysis and modelling of port systems according to ecological and socio-economic criteria. According to the results of the scientific studies in case of the Republic of Croatia, it was concluded that it was possible to design the port system according to the following proposed models shown in Figure 1.

Proposed examples of sea port model systems analysed on the territory of the Republic of Croatia can be applied to any European or world area. Defined criteria for implementation of MoS in the function of environmental protection have no spatial dependence.

\section{MULTI-CRITERIA OPTIMIZATION METHOD REGARDING THE SUSTAINABILITY OF MOS}

The observed method requires defining a general model and then a solution is obtained by using a computer program such as Visual PROMETHEE for
Promethee method, based on different models of implementation of MoS. A general model in the function of environmental protection that has been set in this paper is presented in Figure 2.

Figure 2 presents the general model of selecting a specific scenario of implementation of MoS. The model is defined according to two different criteria (with their associated sub-criteria) and their mutual values and meanings (weightings). The objective of multi-criteria optimization is the selection of optimal model of implementation of MoS in order to protect the environment according to the defined criteria. In this paper, the above mentioned refers to the five possible models of implementation shown in Figure 2 that are about to be used to examine the functioning of the set scenarios. Considering the present conclusions of the study, the identified scenarios will be analysed through several different levels and combinations of difficulties (weightings) of criteria. The ranking was conducted including the following:

- Only criteria of Emissions of harmful exhaust gases,

- Only criteria of External costs of transport,

- Simultaneous influences of criteria of Emissions of harmful exhaust gases and External costs of transport.

In order to conduct the process of multi-criteria optimization by Visual PROMETHEE method, it is necessary to enter the input parameters in Table 1.

In order to process multi-criteria optimization and to formulate the results of research as clearly as possible, it is necessary to provide an overview of all the relevant criteria and sub-criteria and related 


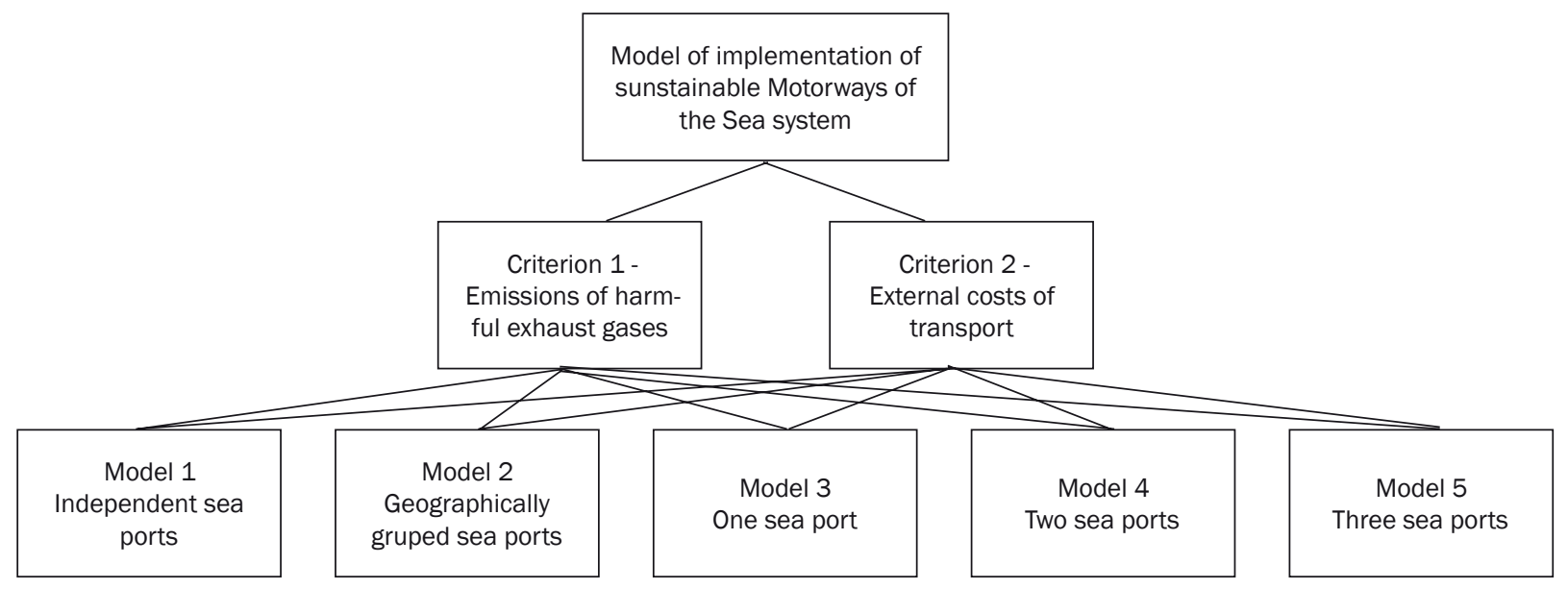

Figure 2 - General model regarding the selection of the implementation of MoS [7]

Table 1 - Input parameters needed for conducting the process of multi-criteria optimization

\begin{tabular}{|c|c|c|}
\hline \multicolumn{3}{|c|}{ Input Parameters } \\
\hline Models of Port Systems & \multicolumn{2}{|c|}{$\begin{array}{l}\text { Model of independent sea ports (the existing model) (ISP) } \\
\text { Model of geographically grouped sea ports (GGSP) } \\
\text { Model of one sea port (1SP) } \\
\text { Model of two sea ports (2SP) } \\
\text { Model of three sea ports (3SP) }\end{array}$} \\
\hline \multirow{5}{*}{ Criteria } & \multirow{2}{*}{ Name of the criterion } & Emissions of harmful exhaust gases \\
\hline & & External costs of transport services \\
\hline & \multicolumn{2}{|c|}{ Evaluation of criteria for a certain model (quantitative data) } \\
\hline & \multicolumn{2}{|c|}{ Defining values of certain criteria (minimal or maximal value) } \\
\hline & \multicolumn{2}{|c|}{ Weighting of certain criteria ( 0 to 3 ) } \\
\hline
\end{tabular}

calculations review of their values for all the proposed models. Evaluation overview, according to criteria and sub-criteria referring to a particular model of the port system which is used to process multiple criteria decision making is shown in Table 2. The values of certain criteria or sub-criteria refer to the result of calculating the emissions of the exhaust gases, energy efficiency and the external costs of transport observed in certain routes. The values in Table 2 have been obtained by calculation set out in section 2 of this paper and guided by the defined port models The calculations were made for complete transport chain/route, including the sea part of the route and land part of the route (rail and road transport system).

While defining the value criteria for ISP, GGSP and 1SP model the following facts has been taken into account. Development of observed defined port models is directed to the container transport system, and all sea ports perform all identified gravitating market and provide infrastructure and superstructure facilities. Based on the aforementioned it can be concluded that each sea port or individual model weighs equal occurrence in the market and attracts the burden on its transport route. In fact, each model needs to ensure large transhipment effects in relation to all defined gravitating markets. While defining the value criteria for 2SP model the following facts have been taken into account. Development of defined model is directed to the container transport system by use of two sea ports of Rijeka and Ploče, which perform and provide infrastructure and superstructure capacity according to the following identified gravitating markets: The port of Rijeka to the markets; Zagreb, Budapest and Belgrade, and Port of Ploče to the markets; Belgrade and Sarajevo. Development of the last defined model is focused on the container transportation system of three sea ports, Rijeka, Zadar and Ploče, which perform and provide infrastructure to the following gravitating markets: Port of Rijeka to markets; Zagreb, Budapest and Belgrade, Port of Zadar to markets; Zagreb, Budapest and Belgrade, Port of Ploče to markets; Belgrade and Sarajevo.

Also, it is important to determine the meanings of individual sub-criteria. The authors consider that all parameters (sub-criteria) are equally important during the process of multi-criteria optimization. The parameters equally participate in environmental pollution (adversely affect human health, flora and fauna) and have same negative effect on the ecological and socio-economic sustainable development of MoS. Therefore, each of them has been given weighting factor 3 . Further research can certainly show whether and which 
Jugović A, Cukrov M, Poletan Jugović T. Multi-criteria Optimization of Motorways of the Sea in the Function of the Environment Protection...

Table 2 - Evaluation overview according to criteria and sub-criteria

\begin{tabular}{|c|c|c|c|c|c|c|c|}
\hline \multirow{2}{*}{ Criteria } & \multirow{2}{*}{ Sub-criteria } & \multirow{2}{*}{ Measuring unit } & \multicolumn{5}{|c|}{ Model of the port system } \\
\hline & & & ISP & GGSP & $1 S P$ & $2 S P$ & $3 S P$ \\
\hline \multirow{7}{*}{$\begin{array}{c}\text { Emissions } \\
\text { of harmful } \\
\text { exhaust } \\
\text { gases }\end{array}$} & Energy consumption & $\begin{array}{l}\text { Number } \\
\text { [MJ/TEU] }\end{array}$ & $8,910.63$ & $8,821.81$ & $7,743.50$ & $6,687.87$ & $7,786.14$ \\
\hline & $\mathrm{CO}_{2}-$ Carbon dioxide & Number [t/TEU] & 0.62 & 0.62 & 0.53 & 0.46 & 0.54 \\
\hline & $\begin{array}{c}\text { NMHC - Non-methane } \\
\text { hydrocarbons }\end{array}$ & Number [kg/TEU] & 0.36 & 0.35 & 0.31 & 0.26 & 0.30 \\
\hline & PM 10 -Particles, soot & Number [kg/TEU] & 0.16 & 0.16 & 0.17 & 0.14 & 0.16 \\
\hline & CO - Carbon monoxide & Number [t/TEU] & 0.60 & 0.59 & 0.51 & 0.44 & 0.52 \\
\hline & NOx - Nitrogen oxide & Number [kg/TEU] & 3.89 & 3.86 & 4.03 & 3.33 & 3.64 \\
\hline & SOx - Sulfur oxide & Number [kg/TEU] & 1.22 & 1.22 & 1.25 & 1.05 & 1.16 \\
\hline \multirow{5}{*}{$\begin{array}{l}\text { External } \\
\text { costs of } \\
\text { transport } \\
\text { services }\end{array}$} & Air pollution & Number [€/TEU] & 96.63 & 93.78 & 84.60 & 71.13 & 80.56 \\
\hline & Climate changes & Number [€/TEU] & 34.21 & 33.70 & 29.54 & 25.20 & 29.25 \\
\hline & Noise & Number [€/TEU] & 18.78 & 18.22 & 15.71 & 13.46 & 15.47 \\
\hline & Accidents & Number [€/TEU] & 5.55 & 5.36 & 4.37 & 3.76 & 4.41 \\
\hline & Congestions & Number [€/TEU] & 23.71 & 23.31 & 17.51 & 15.22 & 19.78 \\
\hline
\end{tabular}

of them can affect differently (can have more or less consequences on the environment) and so a different weighting factor can be given.

Table 3 gives an overview of the output data from Table 2, the meaning of the results of the process of multi-criteria ranking of implementation scenarios of environmentally sustainable MoS by using a computer program VISUAL PROMETHEE. The results refer to the ranking of a particular port system model in relation to the defined criteria. Criteria of Emissions of harmful exhaust gases refer to the total amount of emission of harmful gases into the atmosphere. The criterion of External costs of transport refers to the total amount of ecological and socio-economic costs caused by transport service.

The computer program allows comparing the preferences of a particular model for the impact of each criterion and the combinations of criteria and their respective sub-criteria. According to Table 3, it is clear that the implementation of sustainable MoS, including only the impact of Criteria of Emissions of harmful exhaust gases, the lowest ranked model is the current model - the independent port model. Similarly, the model of grouped ports is ranked adversely and is on the fourth place, while the model of one port is more favourable and ranked third. The table clearly shows that the model of two ports is the best ranked and optimal for implementation, while the model of three ports is located on the second place. Also, it is clear that while implementing sustainable MoS including only the effect of the Criteria of External costs of transport, the model of independent ports is the lowest ranked model. Similarly, the model of grouped ports is ranked adversely and is on the fourth place, while the model of one port is slightly more favourable and ranked third. The table clearly shows that the model of two ports is the best ranked one and optimal for implementation, while the model of three ports is located on the second place.

Including both defined criteria (their simultaneous influences) it is clear that the lowest ranked model is the model of independent port. Similarly, the model of grouped ports is ranked adversely and is on the fourth place, while the model of one port is slightly more favourable and it is ranked third. The table clearly shows that the model of two ports is the best ranked, while the model of three ports is on the second place. It can be concluded that the model of two ports is the most optimal model in case of implementation of a sustainable MoS in the function of environmental protection.

Table 3 - Ranking overview of models according to the influence of criterion

\begin{tabular}{||l|c|c|c|c|c||}
\hline \multirow{2}{*}{ Ranking of models according to the set criteria } & \multicolumn{5}{|c||}{ Model of the port system } \\
\cline { 2 - 6 } & ISP & GGSP & 1SP & 2SP & 3SP \\
\hline \hline According to the criterion of Emissions of harmful exhaust gases & 5 & 4 & 3 & 1 & 2 \\
\hline According to the criterion External costs of transport & 5 & 4 & 3 & 1 & 2 \\
\hline $\begin{array}{l}\text { Simultaneous influences of criteria of emissions of harmful gases, eco- } \\
\text { logical and socio-economic sustainable costs of transport }\end{array}$ & 5 & 4 & 3 & 1 & 2 \\
\hline
\end{tabular}




\section{CONCLUSION}

The analysis of the ranking results of each model of port system shows that the implementation of MoS in certain port traffic system is not simple. It directly depends on the defined criteria and corresponding sub-criteria if it is desired to set up the system in a way that is environmentally and socio-economically viable and efficient for society and the environment. The implementation of above mentioned transport system is the basic condition of effective and efficient protection of the environment and society of particular area involved in the transport route/corridor which may attract more cargo.

The existing model of the functioning of the port system in the Republic of Croatia, Model of independent ports, is not suitable for the development and implementation of ecologically and socio-economically sustainable MoS. The optimal model for implementation is the Model of two ports and the development of gravitating transport infrastructure in relation to the identified gravitating market. The observed model may be considered as optimal solution for the implementation of ecologically and socio-economically sustainable MoS on the example of the port system of the Republic of Croatia, based on conducted scientific research. The implementation of the observed system may contribute to the reduction of the negative consequences due to the rapid development of the transport system and to the economic development of areas involved in its implementation.

\author{
Dr. SC. ALEN JUGOVIĆ ${ }^{1}$ \\ E-mail: ajugovic@pfri.hr \\ Dr. sc. MARIJAN CUKROV ${ }^{2}$ \\ E-mail: cukrov@shortsea.hr \\ Dr. SC. TANJA POLETAN JUGOVIĆ ${ }^{1}$ \\ E-mail: poletan@pfri.hr \\ ${ }^{1}$ Sveučilište u Rijeci, Pomorski fakultet \\ Studentska ulica 2, 51000 Rijeka, Hrvatska \\ 2 Klaster intermodalnog prijevoza \\ Trpimirova 2, 51000 Rijeka, Hrvatska
}

\section{MODEL VIŠEKRITERIJSKE OPTIMIZACIJE SUSTAVA MORSKIH AUTOCESTA U FUNKCIJI ZAŠTITE OKOLIŠA}

\section{SAŽETAK}

Prometni sustav, posebice cestovni sustav prijevoza kao jedan od trenutno najdominantnijih sustava, uzrokuje iznimno štetne posljedice po društvo i okoliš. Očituje se kroz povećanu emisiju štetnih ispušnih plinova, prometna zagušenja, prometne nesreće, povećanu razinu buke te povećani stres i razna oboljenja svih sudionika prometnog sustava te društva općenito. Navedeno je posebice izraženo na gusto naseljenim urbanim područjima. Modernizacija intermodalnog prijevoznog sustava moguća je kroz implementaciju sustava morskih autocesta kao njegova ekološki i socio-ekonomski održivog podsustava i jedan je od načina za smanjenje spomenutih štetnih posljedica. Može se zaključiti kako je od iznimne važnosti osigurati daljnji ekološki i socio-ekonomski održivi razvoj sustava morskih autocesta kako bi isti bio u izravnoj funkciji zaštite društva i očuvanja okoliša.

\section{KLUUČNE RIJEČI}

morske autoceste; luke; zaštita okoliša; intermodalnost; emisije ispušnih plinova; eksterni troškovi; održivi razvoj; energetska učinkovitost;

\section{REFERENCES}

[1] http://ec.europa.eu/transport/sites/transport/files/ themes/strategies/doc/2011_white_paper/white-paper-illustrated-brochure_en.pdf

[2] European Commission. Directorate General for Energy and Transport. Motorways of the Sea. Art. 12a of the TEN-T Guidelines. Brussels, 2005.

[3] López-Navarro M.Á. Environmental Factors and Intermodal Freight Transportation: Analysis of the Decision Bases in the Case of Spanish Motorways of the Sea. Sustainability. 2014;6(3):1544-1566.

[4] Korzhenevych A, Dehnen N, Bröcker J, Holtkamp M, Meier H, Gibson G, Varma A, Cox V. Update of the Handbook on External Costs of Transport. European Commission - DG Mobility and Transport, MOVE/D3/2011/571. Ricardo-AEA; 2014.

[5] Knörr W, Schmied M, Anthes R, Seum S, Kutzner F. EcoTransIT World Initiative - Ecological Transport Information Tool for Worldwide Transports. Berne-Hannover-Heidelberg; 2014.

[6] Janic M. Modelling the full costs of an intermodal and road freight transport network. Transportation Research Part D: Transport and Environment. 2007;12:33-44.

[7] Cukrov M. Model of implementation of the Motorways of the sea system in function of environmental protection [Doctoral dissertation]. University of Rijeka, Faculty of Engineering; 2016.

[8] Brons M, Christidis P. External cost calculator for Marco Polo freight transport project proposals. European Commission, Joint Research Centre. Institute for Prospective Technological Studies, Seville (updated version); 2013. 